\title{
PAMERAN MUSEUM SEBAGAI MEDIA KOMUNIKASI: KAJIAN BERDASARKAN PERSEPSI MODEL KAPLAN
}

\author{
Indah Asikin Nurani \\ (Balai Arkeologi Yogyakarta)
}

\begin{abstract}
Exhibition at the museum is one of the communications media that can be used to present level of civilization and culture of a nation based on cultural materials on display. The essence of communication is the perception that is how visitors are able to accurately perceive the information presented in museum exhibits. Visitor perceptions of accuracy of the information depends on how curator described the encoding within the exhibitions. Formation of a person's perception of the stimulus preceded the arrest sensing nerves, then there's perception of the object, and finally the brain sends impulses through the motor nerve action. Arc sensingperception-reaction in psychology called the reflex arc. This paper describes how far the level of accuracy for the management of visitor perceptions of the exhibition at the Museum Sonobudoyo based on Kaplan's model of four variables namely coherent, easily understood, complexity, and mystery. The data was collected through questionnaires to 65 respondents.
\end{abstract}

Key words: museum, pameran, komunikasi, persepsi

\section{PENDAHULUAN}

Pameran budaya materi (baca: koleksi/objek) museum merupakan salah satu wujud publikasi dalam mempresentasikan tingkat budaya dan peradaban bangsa yang terkait dengan arkeologi publik. Sebagaimana diketahui dalam Arkeologi Publik salah satu bidang kajiannya berkaitan dengan bagaimana mempresentasikan hasil penelitian arkeologi kepada masyarakat. Publikasi yang mempresentasikan hasil penelitian arkeologi bukan hanya berupa penerbitan saja, tetapi juga melingkupi publikasi dalam bentuk yang lain, seperti display/pameran museum, poster, film, dan sosialisasi arkeologi (Prasodjo, 2004). Berdasarkan hal tersebut, maka tampak jelas bahwa museum merupakan salah satu bentuk publikasi dalam Arkeologi Publik. Dalam hal ini, publikasi lebih dimaksudkan untuk menampilkan tingkat peradaban dan kebudayaan suatu bangsa berdasarkan hasil budaya materi (objek/koleksi), yang merupakan karya luhur nenek moyang.

Sesuai dengan fungsi museum sebagai lembaga penelitian, budaya materi koleksi museum harus memenuhi persyaratan tertentu, yaitu 
mempunyai nilai sejarah alam dan budaya, pengetahuan, estetika, serta dapat diidentifikasi wujud (morfologi), tipe (tipologi), gaya (style), fungsi, makna, asal dan periode waktunya. Dengan demikian, koleksi museum menjadi dokumen yang dapat dijadikan kajian ilmiah (Sedyawati, 2001). Sesuai dengan kemajuan ilmu pengetahuan dan metode penelitian, pengelolaan koleksi museum pun mengalami berbagai pengembangan dan terus berusaha mengikuti kemajuan zaman.

Dewasa ini peranan museum tidak lagi dititikberatkan pada pengumpulan dan pelestarian objek warisan budaya, tetapi juga memberikan "pelayanan kebudayaan" kepada masyarakat luas, kepada para ahli, dan pencinta seni. Di lain pihak, dari aspek kesejarahan, museum bukan hanya menjadi tempat konfirmasi dari "kenyataan yang dialami hari ini dan di sini", tetapi juga menjadi titik orientasi atau pijakan untuk memandang dan melangkah ke hari esok. Museum harus mampu merangkum ingatan bersama, sehingga mampu memupuk imajinasi tentang identitas diri maupun masyarakat. Dengan demikian apresiasi masyarakat atau publik terhadap museum diharapkan dapat mengikis pandanganpandangan sempit (etnosentris), tetapi sebaliknya dapat membentuk sikap penghargaan terhadap keragaman budaya (Tanudirdjo, 2007).

Berdasarkan kerangka pikir tersebut, secara umum publik berkepentingan dengan keberadaan museum. Pameran-pameran di museum selalu mengandung nilai-nilai yang merupakan rekam jejak (track record) peradaban dan kebudayaan masyarakatnya. Perlu dipahami bahwa masyarakat sekarang adalah pembuat sejarah bagi masyarakat masa yang akan datang, sedangkan sejarah di masa kini dibuat oleh masyarakat masa lalu. Melalui pameran koleksi museum dapat juga dijelaskan relasi nyata antara museum (dengan segala perangkat pengelolaannya) dengan masyarakat luas atau publik (Subarnas, 2005).

Hubungan tersebut setidaknya dapat tercermin dari museummuseum negeri di Indonesia, termasuk Museum Negeri Sonobudoyo Yogyakarta. Museum ini merupakan museum umum tingkat provinsi, yang sajian koleksinya seharusnya dapat mencerminkan rekam jejak perkembangan peradaban dan kebudayaan Daerah Istimewa Yogyakarta dan sekitarnya. Penyajian pameran tetap Museum Sonobudoyo menampilkan jejak budaya sejak masa prasejarah hingga budaya kontemporer. Sajian koleksi itu ditempatkan di dua unit bangunan Museum Sonobudoyo Unit I dan Unit II. Jarak lokasi kedua museum ini sekitar 700 $\mathrm{m}$, meskipun keduanya berada di pinggiran alun-alun utara Yogyakarta. Museum Sonobudoyo Unit I berada sekitar $300 \mathrm{~m}$ sebelah utara Masjid Agung, sedangkan Museum Sonobudoyo Unit II berada di sebelah timur alun-alun utara. Museum Sonobudoyo Unit I memamerkan tinggalan budaya masa prasejarah hingga budaya kontemporer, termasuk koleksi etnografi, sedangkan Museum Sonobudoyo Unit II lebih banyak memamerkan koleksi budaya kontemporer khusus Daerah Istimewa Yogyakarta. Kedua unit ini menempati lokasi yang strategis karena berada dipusat kota, tepatnya di kawasan $0 \mathrm{~km}$ Yogyakarta, dan sekaligus berada 
di lingkungan pusat budaya Kraton Yogyakarta. Karena itu, museum ini mendapatkan perhatian dari berbagai pihak, baik dari dalam maupun luar negeri. Namun demikian, keunggulan itu belum didukung dengan programprogam museum yang menyatu dan bersinergis dengan kegiatan Kraton Yogyakarta, sehingga dapat dikembangkan sebagai satu paket wisata budaya yang menarik. Kondisi ini mengakibatkan kehadiran dan peran museum ini masih belum dapat dirasakan manfaatnya oleh masyarakat secara maksimal.

Bangunan Museum Sonobudoyo Unit I merupakan rumah joglo dengan Model Masjid Kraton Kasepuhan Cirebon yang didesain oleh Ir. Th Karsten $^{16}$. Keberadaan museum ini erat hubungannya dengan berdirinya Java Institute, yayasan masa kolonial yang bergerak dalam bidang Kebudayaan Jawa, Madura, Bali dan Lombok. Yayasan inilah yang memprakarsai berdirinya Museum Sonobudoyo. Oleh karenanya koleksikoleksi yang ada di Museum Sonobudoyo meliputi berbagai kebudayaan di wilayah tersebut. Museum Sonobudoyo diresmikan pada tanggal 6 Nopember 1935 oleh Sri Sultan Hamengkubuwono VIII yang ditandai dengan Candrasengkala Kayu Winayang ing Brahmana Budha "9 Ruwah 1889 Tahun Jawa" (Anonim, 2001). Adapun bangunan unit II berada di timur alun-alun utara, tepatnya di Wijlan, yang dikenal dengan sebutan Museum Condrokiranan.
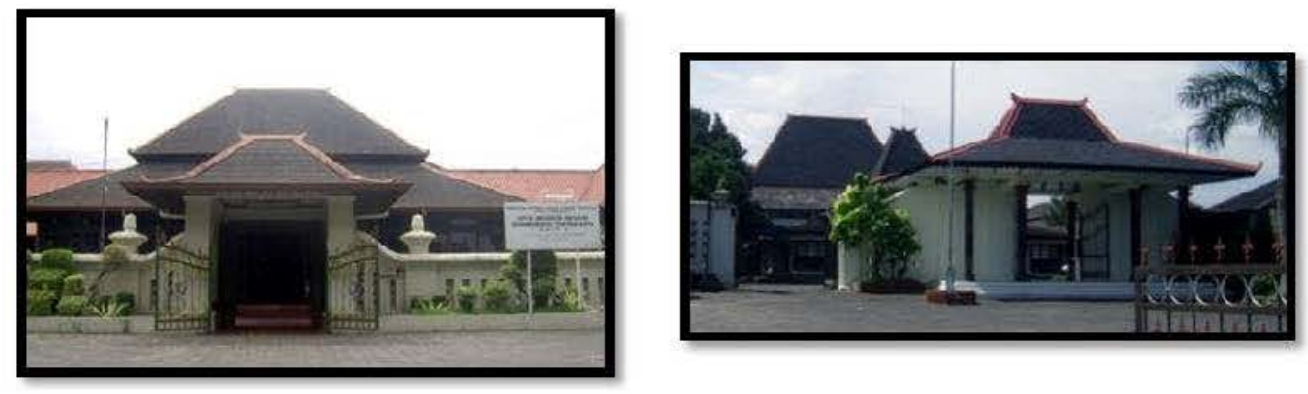

Foto 1. Museum Negeri Sonobudoyo Unit I (kiri) dan Unit II (kanan). Sumber: dok. penulis

Sesuai dengan fungsinya, Museum Negeri Sonobudoyo mempunyai tugas utama mengungkapkan dan menginformasikan nilai-nilai budaya yang dapat membuktikan jejak peradaban dan kebudayaan Provinsi Daerah Istimewa Yogyakarta dan sekitarnya. Tugas utama museum tersebut didukung dengan pengelolaan informasi dalam beberapa kemasan yaitu kemasan tulis, lisan, dan visual sebagai media komunikasi museum kepada publik. Ketiga kemasan informasi yang tersedia di Museum Sonobudoyo cenderung didominasi kemasan tulis saja antara lain berupa leaflet, buku panduan, bulletin, dan beberapa kajian berkaitan dengan koleksi. Kemasan lisan meliputi pemanduan (guiding) yang dilakukan oleh Seksi Bimbingan,

16 Sayang kemegahan bangunan museum tersebut, seolah tenggelam karena pada bagian depan museum dipagari pedagang kaki lima. Hal tersebut berakibat kemegahan gedung museum tidak tampak dari jalan raya, bahkan pintu masuk museum pun tidak kelihatan. 
saresehan, dan ceramah. Kemasan visual yang ada berupa pameran tetap dan temporer, papan-papan informasi, dan teks-teks informasi koleksi, serta VCD/DVD profil museum dan website. Sementara itu, kemasan visual digital berupa CD-Interaktif, slide show, dan olah grafis seperti poster, art photo, dan album belum tersedia.

Semestinya pengelolaan informasi dalam bentuk pameran dengan kemasan tulis, lisan, maupun visual yang tersedia di Museum Sonobudoyo dapat menjadi bagian penyajian informasi yang komunikatif dan mudah dipahami. Untuk itu, peran kurator sebagai konseptor pameran museum menjadi penentu berhasil tidaknya presentasi koleksi museum melalui informasi yang disajikan. Kurator harus memahami bagaimana koleksi museum sebagai benda simbolis dapat mempunyai nilai penting (signifikan) dan bermakna baik bagi generasi penciptanya maupun generasi selanjutnya melalui interpretasi yang disajikan kepada masyarakat (Poespowardojo, 1993/1994). Hasil interpretasi dapat diinformasikan atau dikomunikasikan secara langsung maupun dengan kemasan tertentu. Interpretasi langsung dilakukan melalui pemanduan (guiding) sedangkan interpretasi kemasan ("dead interpretation") antara lain meliputi pameran, leaflet, label, audiovideo, IT system (multi media), tata suara, musik, replika, dan contoh/peniruan (Howard, 2003). Berbagai kemasan informasi yang dipresentasikan tersebut idealnya memiliki tingkat kesesuaian persepsi yang sama antara pengelola museum sebagai komunikator (pemberi pesan) dengan publik atau pengunjung museum sebagai komunikan (penerima pesan). Akan tetapi kenyataannya kemasan informasi yang dipresentasikan dalam pameran Museum Sonobudoyo belum sepenuhnya dipersepsi pengunjung sesuai yang diharapkan pengelola museum. Hal tersebut salah satunya disebabkan karena koleksi yang dipresentasikan belum terjabarkan secara komunikatif dan mudah dipahami. Selain itu, konsep persepsi dalam presentasi melalui pameran belum diterapkan sepenuhnya.

Berdasarkan uraian tersebut di atas, dapat diketahui bahwa museum mempunyai fungsi untuk memberikan informasi kepada masyarakat/publik melalui koleksi yang dipamerkan. Salah satu informasi yang terpenting adalah menggambarkan dan menjelaskan kebudayaan dan peradaban yang dapat menjadi identitas lokal khususnya maupun nasional pada umumnya. Berkaitan dengan hal tersebut, aspek komunikasi menjadi sangat penting untuk menyampaikan berbagai informasi tersebut sehingga dapat berkembang sebagai jendela memaknai peradaban zaman. Untuk itu dalam tulisan ini akan dibahas dua permasalahan yang terkait dengan komunikasi di museum. Pertama, bagaimana pengelolaan informasi di Museum Negeri Sonobudoyo, dalam berbagai bentuk kemasannya dapat menjadi media komunikasi antara pengelola dengan pengunjung museum? Kedua, seberapa tinggi kesesuaian persepsi antara pengelola dengan pengunjung museum dalam menanggapi informasi yang dipamerkan?

Kedua permasalahan di atas akan diungkap melalui kajian berdasarkan konsep persepsi model Kaplan. Sebagaimana telah diuraikan di atas bahwa pameran merupakan media komunikasi, sedangkan inti dari 
komunikasi adalah persepsi. Persepsi disebut inti komunikasi, karena jika persepsi tidak akurat, tidak mungkin terjadi komunikasi yang efektif. Persepsi akan menentukan dipilihnya suatu pesan dan mengabaikan pesan yang lain. Semakin tinggi derajat kesamaan persepsi antara komunikator dengan komunikan, semakin mudahlah terjadinya komunikasi (Mulyana, 2007). Persepsi itu sendiri pada dasarnya merupakan bagian kajian dari ilmu psikologi. Pendekatan ini dapat digunakan untuk menjawab permasalahan di atas. Dalam kasus ini, akan digunakan persepsi model Kaplan yang menganggap bahwa keberhasilan komunikasi tergantung pada empat variabel yaitu, koheren, legibility (selanjutnya disebut 'mudah difahami'), kompleks, dan misteri (Sarwono, 1992).

\section{PERSEPSI SEBAGAI INTI KOMUNIKASI}

Komunikasi adalah proses penyampaian pesan yang dilakukan oleh komunikator kepada komunikan melalui media yang menimbulkan efek tertentu. Pesan yang disampaikan komunikator kepada komunikan terdiri atas isi (content) dan lambang (symbol). Kegiatan komunikasi tidak hanya penyampaian pesan yang informatif yakni agar orang lain mengerti dan tahu, tetapi juga persuasif yaitu agar orang lain bersedia menerima suatu paham atau keyakinan melalui suatu perbuatan atau kegiatan. Jadi, fungsi komunikasi di antaranya adalah menyampaikan informasi, mendidik, menghibur, dan mempengaruhi. Untuk itu, seorang komunikator dalam proses komunikasi dituntut dapat memahami keadaan dan sifat-sifat dari sasaran (target audience). Selain itu pemahaman tentang apa, siapa, dan bagaimana sasaran yang dituju, juga menjadi landasan seorang komunikator dalam berkomunikasi. Hal tersebut dimaksudkan agar semua yang disampaikan akan mengena dan efisien. Pesan akan percuma jika tidak dipahami oleh penerimanya. Dengan demikian sebelum melakukan penyampaian pesan, harus dipahami dulu apa dan siapa sasaran yang dituju. Setelah itu baru menentukan bagaimana pesan tersebut disampaikan (Effendy, 2003).

Bentuk komunikasi sebagaimana diuraikan di atas, tidak berbeda dengan bentuk komunikasi yang ideal dalam pengelolaan pameran di museum. Menurut Hooper-Greenhill (1999) bentuk komunikasi melalui pameran museum pada dasamya adalah menyampaikan gagasan dan masukan berdasarkan pengamatan ilmiah. Masukan atau gagasan dalam hal ini merupakan feedback yang menjadi dasar evaluasi sebagaimana yang dijabarkan Effendy (2003) dalam siklus komunikasi. Lebih lanjut Hooper-Greenhiil menjabarkan komunikasi yang mendasari pameran museum dalam bagan sebagai berikut. 


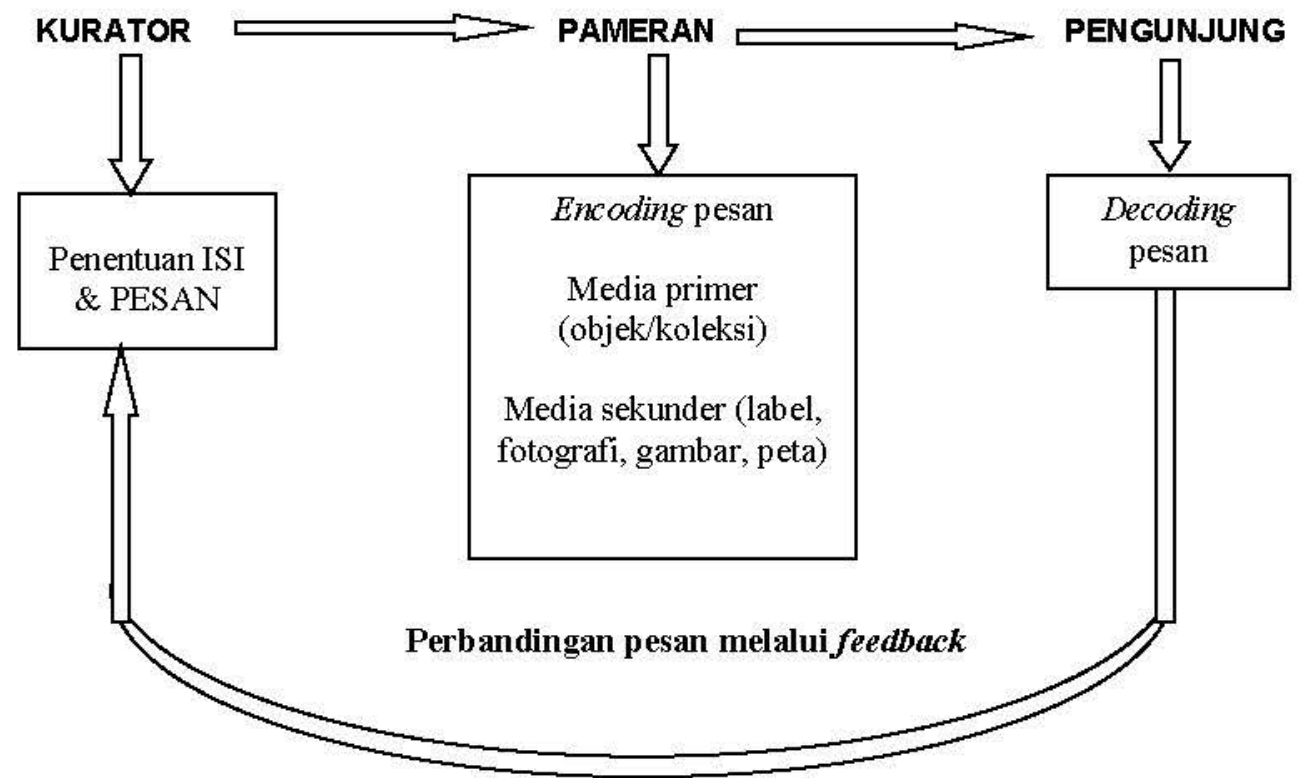

Sumber: Hooper-Grenhill, 1999:37, diterjemahkan penulis dengan modifikasi

Bagan di atas menunjukkan bahwa media pameran akan dapat dipahami pengunjung apabila penyajiannya menggunakan media-media primer (koleksi museum) dan media sekunder (fotografi, poster, label, gambar, dan peta).

Proses komunikasi dalam media pameran museum dimulai dari penentuan isi dan pesan kurator sebagai komunikator dalam mempresentasikan koleksi museum. Selanjutnya, isi dan pesan yang akan dipresentasikan melalui pameran yang masih berupa encoding (penyandian yaitu proses pengalihan pikiran ke dalam bentuk lambang) dikelola dalam story line yang mempertimbangkan kaidah-kaidah ilmiah. Sebagaimana dalam siklus komunikasi, encoding pesan tersebut yang terdiri atas media primer dan media sekunder dalam kemasan informasi pameran diterima komunikan (pengunjung) melalui persepsi yaitu dekoding (pengawasandian). Langkah-langkah menyusun pesan (encoding) hingga dekoding agar dapat dipersepsi publik/pengunjung secara akurat, perlu dirumuskan dalam strategi pengelolaan pameran. Sebagaimana telah diuraikan dalam persepsi model Kaplan, pesan yang dipresentasikan dalam pameran haruslah koheren, mudah difahami, kompleks, dan mengandung misteri.

Persepsi merupakan konsep yang sangat penting dalam psikologi, kalau bukan dikatakan yang paling penting. Melalui persepsilah manusia memandang dunianya, apakah dunia terlihat "berwarna" cerah, pucat, atau hitam. Semua itu adalah persepsi manusia yang bersangkutan. Persepsi merupakan proses aktif manusia dalam memilah, mengelompokkan, serta memberikan makna pada informasi yang diterimanya (Setyanto, 2009). 
Pembentukan persepsi seseorang didasarkan pada pengalaman dalam menangkap informasi. Proses ini diawali oleh penginderaan, yaitu ditangkapnya rangsang-rangsang dari lingkungan oleh alat-alat indera manusia. Selanjutnya, hasil penginderaan berupa impuls-impuls disalurkan melalui syaraf-syaraf penginderaan ke sistem syaraf pusat di otak, sehingga terjadi persepsi mengenai objek tersebut. Kemudian, otak mengirim impulsimpuls melalui syaraf motorik untuk memerintahkan otot-otot atau kelenjarkelenjar tertentu untuk beraksi. Proses "penginderaan-persepsi-reaksi" dalam psikologi dinamakan busur refleks. Sementara itu, menurut psikologi lingkungan secara konvensional, persepsi didefinisikan sebagai adanya rangsang dari luar diri individu (stimulus), kemudian individu menjadi sadar akan adanya stimuli ini melalui sel-sel syaraf reseptor (penginderaan) yang peka terhadap bentuk-bentuk energi tertentu (cahaya, suara, suhu). Bila sumber energi itu cukup kuat untuk merangsang sel-sel reseptor maka terjadilah penginderaan. Jika sejumlah penginderaan disatukan dan dikoordinasikan di dalam pusat syaraf yang lebih tinggi (otak), maka manusia dapat mengenali dan menilai objek-objek. Secara umum pandangan konvensional ini menganggap kesenjangan persepsi sebagai kumpulan penginderaan. Kumpulan penginderaan ini akan dikoordinasikan secara tertentu, dikaitkan dengan pengalaman dan ingatan masa lalu dan diberi makna tertentu (Sarwono, 1992).

Pengertian persepsi sebagaimana diuraikan di atas menunjukkan bahwa indera manusialah yang menentukan terbentuknya persepsi. Semakin banyak indera yang menerima stimulus, maka semakin akuratlah persepsi terbentuk. Selain itu pembentukan persepsi juga didasarkan pada situasi dan sikap tertentu atau ecological perception yang terbagi atas dua hal. Pertama, stimulus lingkungan yang merupakan segala sesuatu yang terdapat di lingkungan (penyesuaian timbal balik antara individu sosial dengan lingkungan fisiknya). Kedua, kemampuan persepsi memungkinkan seseorang untuk menafsirkan objek dengan berbagai fungsi yang dimiliki misalnya: topeng berfungsi sebagai penutup muka (Sarwono, 1992).

\section{Metode pengumpulan data}

Pengumpulan data untuk mengetahui tingkat persepsi pengunjung museum terhadap kemasan informasi yang tersedia di Museum Negeri Sonobudoyo dilakukan dengan penyebaran kuesioner kepada pengunjung. Teknik pengambilan sampel dilakukan secara probabilitas (probability sampling), yang ditentukan dalam waktu 2 (dua) minggu dengan cara klaster (cluster random sampling) yaitu melakukan randomisasi terhadap kelompok, bukan terhadap subjek secara individual semata (Azwar, 1998). Penyusunan daftar pertanyaan kuesioner didasarkan pada penyusunan kisikisi terlebih dahulu yaitu menetapkan variabel, definisi operasional, indikator, item pertanyaan, dan pengukuran. Penetapan keempat variabel sebagaimana telah dijelaskan di atas meliputi koheren, mudah difahami, kompleks, dan misteri. Adapun definisi operasional dan indikator keempat variabel adalah sebagai berikut: 
1) Koheren: informasi tentang museum terorganisir dengan baik dalam kemasan lisan, tulis, dan visual. Indikator koheren adalah komunikatif, urutan/kronologi kesejarahan, dan desain serta tampilan yang menarik;

2) Mudah difahami adalah tingkatan isi informasi yang dapat dibedakan pemahamannya dan kategorinya. Indikatornya adalah dekoding dalam pemahaman, makna, dan tafsiran atau interpretasi terhadap informasi kemasan tulis dan visual;

3) Kompleksitas, jumlah dan variasi informasi. Indikatomya meliputi variasi informasi yang kompleks, tampilan yang variatif, dan keragaman warna; dan

4) Misteri adalah tingkatan informasi yang menimbulkan cuniosity atau keingintahuan lebih lanjut. Indikatornya adalah bentuk informasi yang menimbulkan keingintahuan lebih lanjut dalam bentuk teks, foto, gambar, dan ilustrasi.

Keempat variabel tersebut akan dikaji satu per satu sebagai indikator tingkat akurasi persepsi pengunjung museum atas kemasan informasi yang dipresentasikan dalam pameran museum.

Selanjutnya dalam pengukurannya terdapat dua cara pengukuran yaitu pengukuran dengan menilai pilihan jawaban dan pengukuran dengan prosentase. Penilaian jawaban dilakukan dengan memberikan nilai 1 hingga 4 atas jawaban pertanyaan. Jika menjawab (a) sangat jelas diberi nilai 4; (b) jelas diberi nilai 3; (c) kurang jelas diberi nilai 2; dan (d) tidak jelas diberi nilai 1. Sementara itu pengukuran dengan prosentase, dilakukan terhadap pilihan jawaban "ya" atau "tidak" untuk mengetahui berapa persen yang menjawab "ya" dan yang menjawab "tidak". Setelah itu, hasil digabungkan untuk mengetahui tingkat kesenjangan antara kinerja museum dengan tingkat akurasi persepsi pengunjung.

\section{PERSEPSI PENGUNJUNG ATAS KEMASAN INFORMASI MUSEUM SONOBUDOYO}

Pameran Museum Sonobudoyo sebagai media komunikasi museum kepada pengunjung (publik), dalam penyajiannya mempresentasikan gambaran secara kronologi budaya masa prasejarah sampai dengan budaya kontemporer Provinsi Daerah Istimewa Yogyakarta dan sekitamya. Penyajian koleksi meliputi koleksi unggulan dan story line atau alur cerita yang menyeluruh dan menjadi karakter Museum Sonobudoyo sebagai bagian dari Java Institute yang meneliti budaya dan sejarah peradaban Jawa, Madura, Bali, dan Lombok. Meskipun dalam penyajiannya masih kurang mencerminkan keseluruhan jejak kebudayaan dan peradaban yang pernah berlangsung di Jawa khususnya di Provinsi Daerah Istimewa Yogyakarta dan sekitarnya, namun pameran Museum Sonobudoyo telah berusaha membandingkan kebudayaan Jawa dengan kebudayaan Bali. 

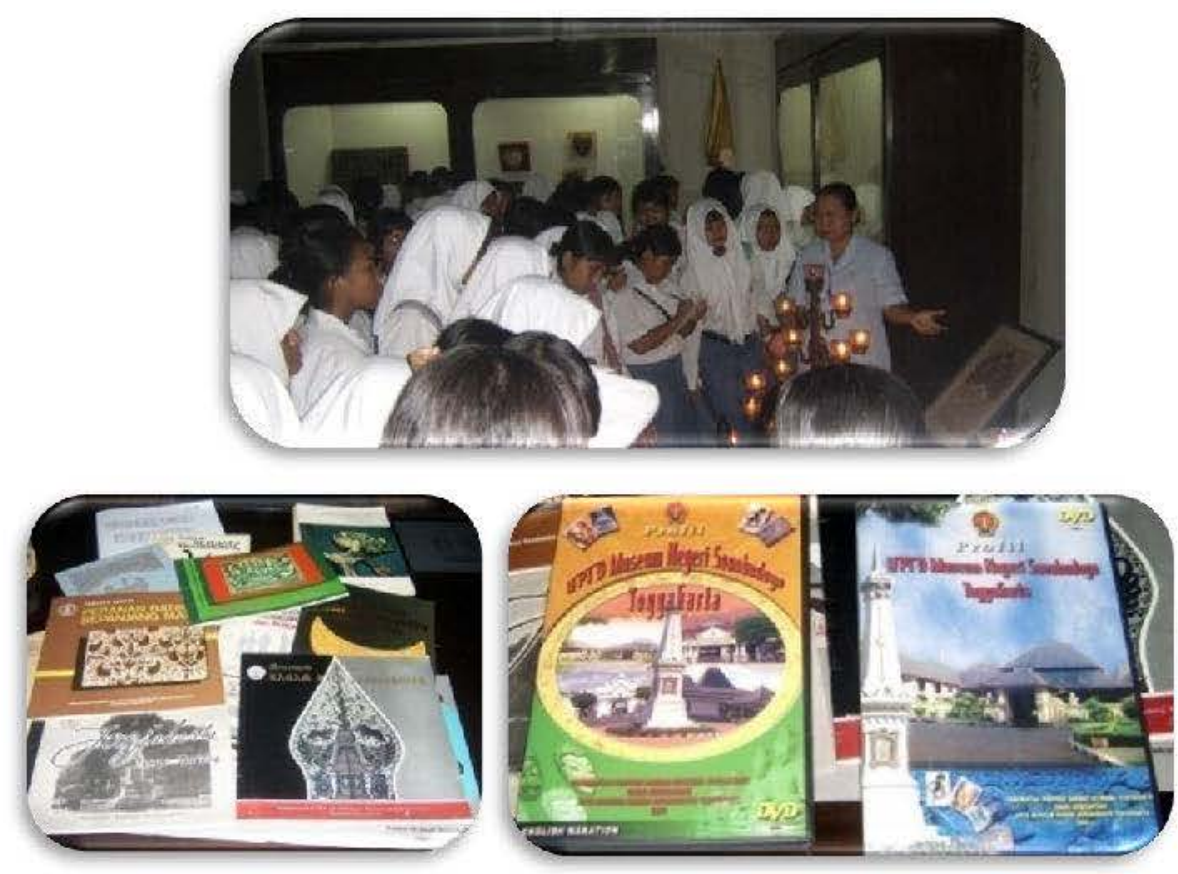

Foto 2. Kemasan informasiyang tersedia ai Muse um Sonobudoyo hisan (atas), tulis (kïr), don visual (konan). Sumber: dokumentasi penulis

Melalui penyebaran kuesioner selama dua minggu kepada pengunjung Museum Sonobudoyo, berhasil diperoleh 65 responden. Hasil pengukuran terhadap jawaban 65 responden secara umum menunjukkan bahwa hampir semua variabel persepsi, baik koherensi, kemudahan difahami, kompleksitas, maupun misteri, terhadap kemasan informasi yang tersedia di Museum Sonobudoyo menunjukkan nilai "jelas" dengan nilai rata-rata kurang dari 3 .

Hasil pengukuran indikator variabel koheren yang meliputi tingkat kejelasan dan tampilan informasi baik kemasan lisan/pemandu, tulis, maupun visual menunjukkan bahwa kinerja museum masih mendapat nilai di bawah 3 dari nilai ideal 4 (lihat Tabel 01), yang berarti cukup jelas. Adapun pilihan jawaban "ya" dan "tidak" yang meliputi 2 pertanyaan untuk indikator desain dan keterkaitan antara informasi baik kemasan tulis maupun visual menunjukkan lebih dari $70 \%$ responden menjawab "ya" (lihat Tabel 02). Secara terinci 16 responden atau $25 \%$ menganggap desain teks tidak menarik dan tidak mudah dibaca, 49 responden lainnya atau $75 \%$ menjawab menarik dan mudah dibaca. Sementara itu, dalam hal desain visual, 10 responden atau $15 \%$ menganggap tidak menarik dan tidak mudah terlihat, sedangkan 55 responden lainnya atau $85 \%$ menganggap desain visual sudah menarik dan mudah terlihat. Untuk keterkaitan antara informasi tulis, 13 responden atau $20 \%$ menganggap kemasan tulis tidak ada keterkaitan, 52 responden lainnya atau $80 \%$ menganggap antara informasi tulis saling berhubungan. Mengenai keterkaitan antara informasi visual, 17 responden atau $26 \%$ menganggap antara informasi visual tidak ada 
keterkaitan, dan 48 responden lainnya atau $74 \%$ menganggap antara informasi visual ada saling hubungan. Atas dasar perolehan data tersebut, maka pelayanan informasi Museum Sonobudoyo baik kemasan lisan, tulis, maupun visual kurang koheren.

Tabel 01. Pengukuran Pilihan 1 - 4: Variabel Koheren

\begin{tabular}{|c|c|c|c|c|c|}
\cline { 2 - 6 } \multicolumn{1}{c|}{} & LISAN & \multicolumn{3}{c|}{ INFORMASI KEMASAN TULIS } \\
\cline { 2 - 6 } \multicolumn{1}{c|}{} & pemandu & leaflet & booklet & brosur & kaji koleksi \\
\hline KINERJA & 2.63 & 2.78 & 2.68 & 2.48 & 3 \\
\hline NILAI IDEAL & 4 & 4 & 4 & 4 & 4 \\
\hline
\end{tabular}

\begin{tabular}{|c|c|c|c|c|c|c|c|}
\cline { 2 - 8 } \multicolumn{1}{c|}{} & \multicolumn{4}{c|}{ INFORMASI VISUAL } & \multicolumn{3}{c|}{ TAMPILAN } \\
\cline { 2 - 9 } \multicolumn{1}{c|}{} & foto & $\begin{array}{c}\text { gmb/ } \\
\text { peta }\end{array}$ & $\begin{array}{c}\text { papan } \\
\text { informasi }\end{array}$ & $\begin{array}{c}\text { label } \\
\text { koleksi }\end{array}$ & pemandu & tulis & visual \\
\hline KINERJA & 2.92 & 2.94 & 2.82 & 2.78 & 2.65 & 2.66 & 2.74 \\
\hline NILAI IDEAL & 4 & 4 & 4 & 4 & 4 & 4 & 4 \\
\hline
\end{tabular}

Tabel 02. Pengukuran Prosentase (jawaban YA) Variabel Koheren

\begin{tabular}{|l|r|r|r|r|}
\cline { 2 - 5 } \multicolumn{1}{c|}{} & \multicolumn{2}{c|}{ DESAIN } & \multicolumn{2}{c|}{ KETERKAITAN } \\
\cline { 2 - 5 } \multicolumn{1}{c|}{} & \multicolumn{1}{c|}{ Teks } & \multicolumn{1}{c|}{ Visual } & \multicolumn{1}{c|}{ Tulis } & \multicolumn{1}{c|}{ Visual } \\
\hline KINERJA & $49 / 75 \%$ & $55 / 85 \%$ & $52 / 80 \%$ & $48 / 74 \%$ \\
\hline SELURUH RESPONDEN & 65 & 65 & 65 & 65 \\
\hline
\end{tabular}

Pengukuran variabel kedua, yaitu tingkat mudah difahami dengan indikator tingkat pemahaman, makna, dan tafsiran, juga menunjukkan nilai rata-rata di bawah 3 yang berarti mudah difahami. Adapun pilihan jawaban "ya" atau "tidak" untuk indikator informasi baik tulis maupun visual menunjukkan lebih dari $75 \%$ menjawab ya atau mudah ditafsirkan. Namun, 11 responden atau $17 \%$ menyatakan tidak dapat menafsirkan informasi tulis dan 54 responden lainnya atau $83 \%$ menyatakan dapat menafsirkan informasi dalam kemasan tulis. Adapun tafsiran informasi kemasan visual, 15 responden atau $23 \%$ menyatakan tidak dapat menafsirkan informasi visual, 50 responden lainnya atau $77 \%$ menyatakan dapat menafsirkan informasi. Dengan demikian, untuk tingkat kemudahan dipahami kemasan informasi tulis dan visual menunjukkan mudah difahami.

Tingkat kompleksitas baik kemasan tulis maupun visual dengan indikator kompleks dan variatif menunjukkan tingkat kompleks dengan nilai rata-rata di bawah 3 (Tabel 03). Adapun untuk jawaban "ya" atau "tidak" untuk indikator keragaman kemasan tulis dan visual menunjukkan lebih dari $50 \%$ responden menjawab kemasan informasi tulis dan visual beragam. Secara terinci 26 responden atau $40 \%$ menyatakan informasi kemasan tulis tidak beragam, sedangkan untuk informasi kemasan visual, ada 18 responden atau $28 \%$ yang menyatakan tidak beragam (Tabel 04 ). 
Tabel 03. Pengukuran 1 - 4: Variabel Mudah Difahami dan Komplesitas

\begin{tabular}{|c|c|c|c|c|c|c|c|c|}
\cline { 2 - 9 } & \multicolumn{4}{c|}{ MUDAH DIFAHAMI } & \multicolumn{4}{c|}{ KOMPLEKSITAS } \\
\cline { 2 - 9 } & \multicolumn{1}{c|}{ PEMAHAMAN } & \multicolumn{2}{c|}{ MAKNA } & \multicolumn{2}{c|}{ KOMPLEKSITAS } & \multicolumn{2}{c|}{ VARIASI } \\
\cline { 2 - 9 } & tulis & visual & tulis & visual & tulis & visual & tulis & visual \\
\hline KINERJA & 2.72 & 2.69 & 3.09 & 3.00 & 2.63 & 2.62 & 2.74 & 3 \\
\hline NILAI IDEAL & 4 & 4 & 4 & 4 & 4 & 4 & 4 & 4 \\
\hline
\end{tabular}

Tabel 04. Pengukuran Prosentase (jawaban YA) Variabel Mudah Difahami dan Kompleksitas

\begin{tabular}{|l|r|r|r|r|}
\cline { 2 - 5 } \multicolumn{1}{c|}{} & \multicolumn{2}{c|}{ TAFSIRAN } & \multicolumn{2}{c|}{ RAGAM } \\
\cline { 2 - 5 } \multicolumn{1}{c|}{} & \multicolumn{1}{c|}{ Tulis } & \multicolumn{1}{c|}{ Visual } & \multicolumn{1}{c|}{ Tulis } & \multicolumn{1}{c|}{ Visual } \\
\hline KINERJA & $54 / 83 \%$ & $50 / 77 \%$ & $39 / 60 \%$ & $47 / 72 \%$ \\
\hline SELURUH RESPONDEN & 65 & 65 & 65 & 65 \\
\hline
\end{tabular}

Variabel terakhir adalah unsur misteri dalam penyajian informasi, baik kemasan tulis maupun visual, dengan indikator informasi yang menimbulkan keingintahuan lebih jauh (curiosity). Pengukuran dilakukan hanya dengan satu cara saja yaitu melalui jawaban "ya" atau "tidak" mengenai informasi yang mengandung misteri pada teks, foto, gambar/peta, dan ilustrasi. Hasil pengukuran unsur misteri pada teks menunjukkan 19 responden atau $29 \%$ menyatakan informasi teks tidak mengandung misteri, sedangkan 17 responden atau $26 \%$ menyatakan informasi pada foto tidak mengandung misteri. Untuk informasi berupa gambar/peta ada 15 responden atau $23 \%$ yang menyatakan informasi tidak mengandung misteri. Mengenai ada tidaknya unsur misteri pada ilustrasi, ada 14 responden atau $22 \%$ yang menyatakan informasi tidak mengandung misteri (lihat Tabel 05 ).

Tabel 05. Pengukuran Prosentase (jawaban YA) Variabel Misteri

\begin{tabular}{|l|c|c|c|c|}
\cline { 2 - 5 } \multicolumn{1}{c|}{} & \multicolumn{4}{c|}{ MISTERI } \\
\cline { 2 - 5 } \multicolumn{1}{c|}{} & Teks & Foto & Gambar & llustrasi \\
\hline KINERJA & $46 / 71 \%$ & $48 / 74 \%$ & $50 / 77 \%$ & $51 / 78 \%$ \\
\hline SELURUH RESPONDEN & 65 & 65 & 65 & 65 \\
\hline
\end{tabular}

Berdasarkan analisis terhadap jawaban kuesioner yang disebarkan kepada 65 pengunjung Museum Sonobudoyo, dengan pengukuran 4 variabel persepsi (koherensi, kemudahan dipahami, kompleksitas, dan misteri), dapat diketahui secara umum tingkat persepsi pengunjung terhadap informasi yang disajikan di museum tersebut, baik dalam kemasan lisan, tulis, maupun visual. Hasil tersebut dapat dilihat dari grafik tingkat persepsi pengunjung di bawah ini. Grafik tersebut menunjukkan bahwa secara umum kinerja museum masih berada di bawah nilai 3 . Artinya, komunikasi antara kurator museum dengan pengunjung masih di bawah harapan jika dibandingkan dengan harapan pengunjung yang diwakili dengan nilai ideal 4 . 


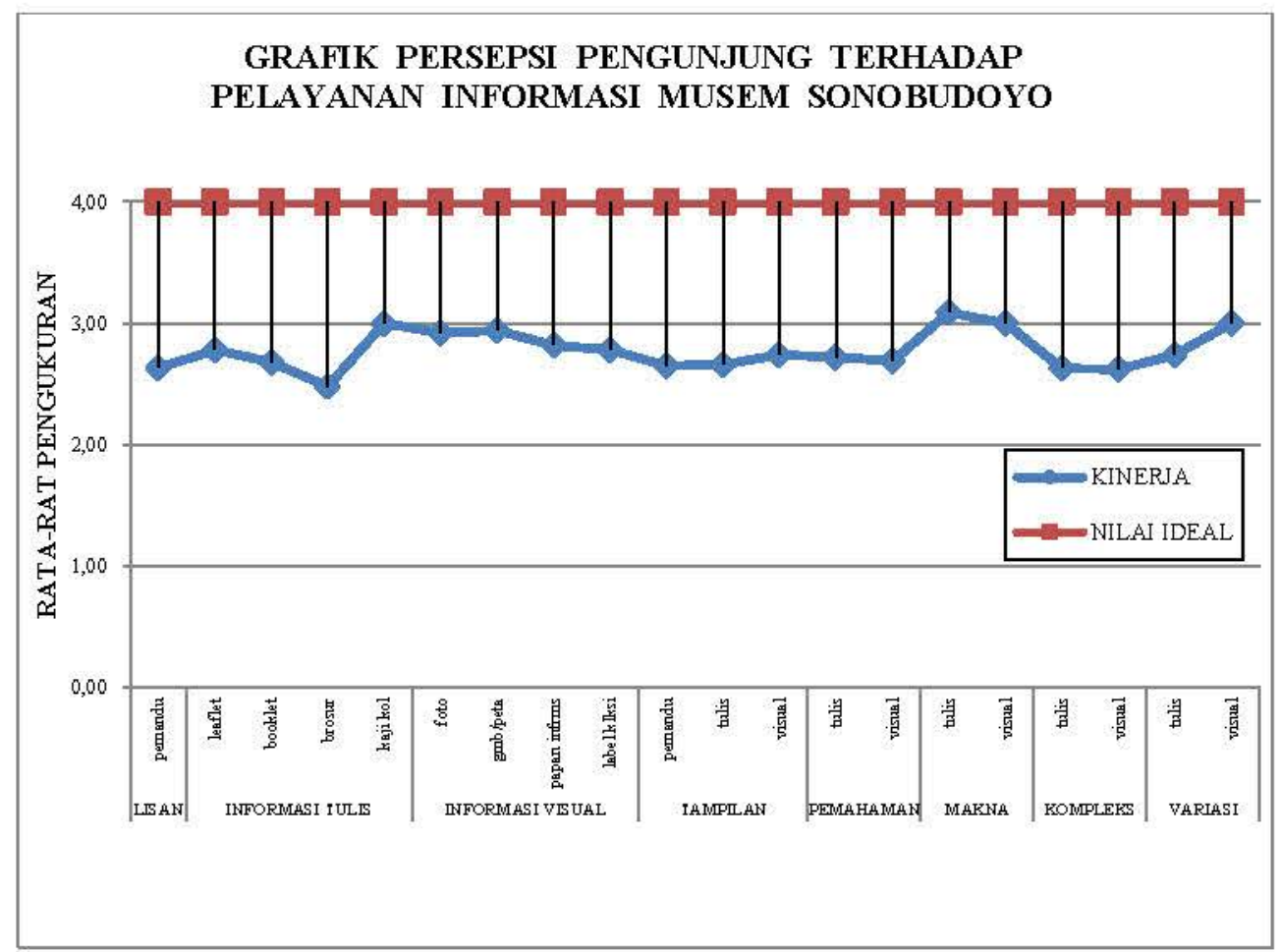

Grafik di atas menunjukkan terjadi kesenjangan dalam pengelolaan informasi sebagai kinerja Museum Sonobudoyo dengan persepsi pengunjung. Kesenjangan tertinggi (nilai 2,5) terjadi pada penyajian kemasan tulis berupa brosur, leaflet, dan buku panduan. Kesenjangan selanjutnya, yang lebih rendah, terlihat pada indikator tampilan, tingkat pemahaman, dan kompleksitas informasi kemasan tulis dan visual. Dalam penyajian informasi baik kemasan tulis maupun visual terdapat kesenjangan cukup tinggi terutama pada keragaman, unsur misteri, keterkaitan antara informasi, dan desain. Pengukuran kesenjangan dalam hal ini dilakukan dengan menilai dua pilihan jawaban 'ya' atau 'tidak'. Apabila seluruh pengunjung menjawab ya berarti tidak ada kesenjangan. Berikut tabel dan grafik persepsi harapan pengunjung dengan pengukuran jawaban ya. 


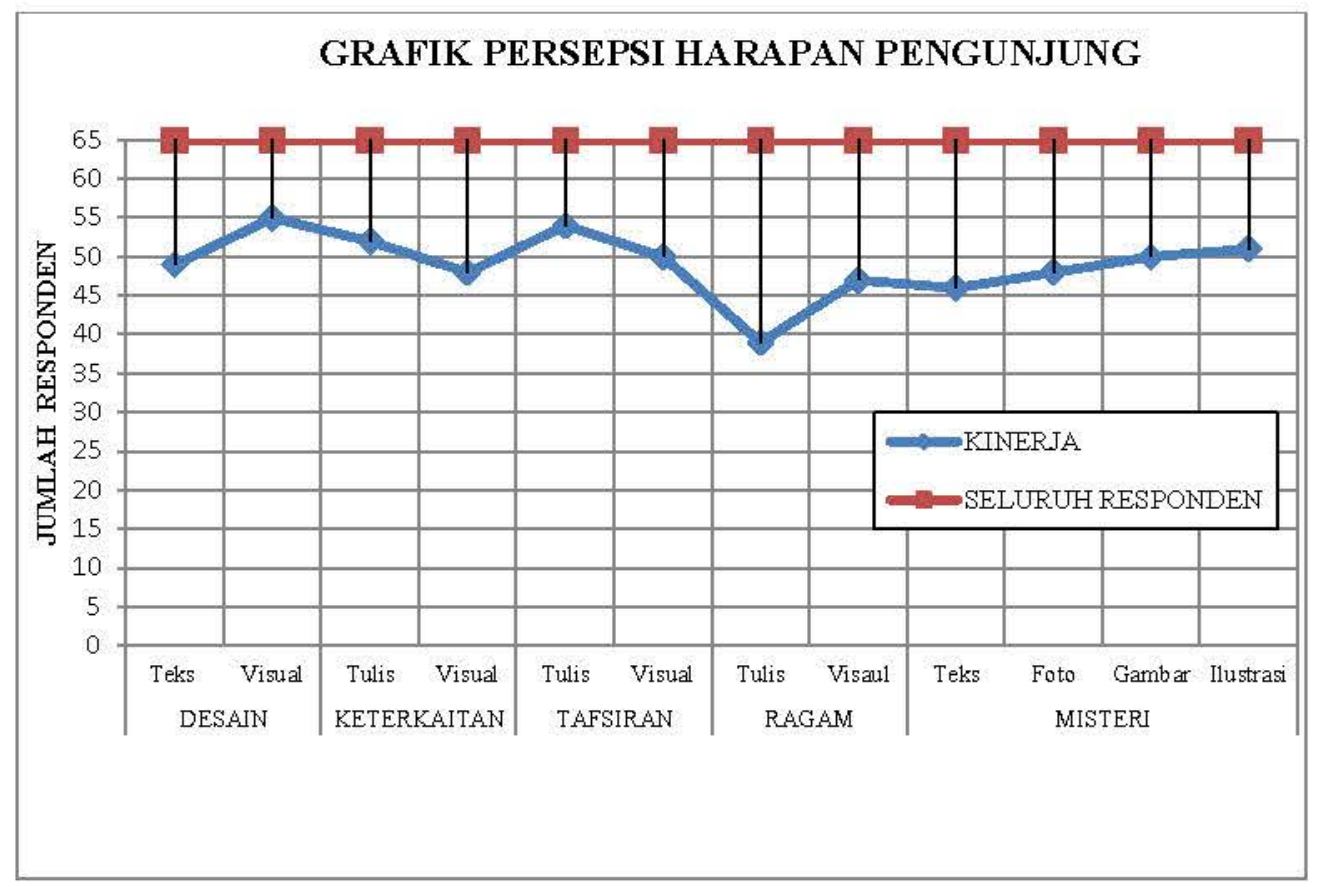

Grafik di atas menunjukkan seluruh variabel persepsi yaitu koheren, mudah difahami, kompleksitas, dan misteri yang diukur dengan jawaban 'ya' atau 'tidak'. Persepsi koheren ditunjukkan dengan indikator 'desain' dan 'keterkaitan antara informasi'; variabel 'mudah difahami' dengan indikator 'tafsiran'; variabel 'kompleksitas' dengan indikator 'ragam'; dan variabel 'misteri' dengan indikator informasi yang menimbulkan keingintahuan lebih lanjut pada teks, foto, gambar/peta, dan ilustrasi. Berdasarkan grafik di atas tampak jelas bahwa kesenjangan tertinggi terdapat pada ragam informasi kemasan tulis, sedangkan kesenjangan terendah ada pada desain informasi kemasan visual. Adapun keterkaitan antara informasi dan misteri menunjukkan tingkat kesenjangan yang setara. Berdasarkan hal tersebut, dapat diketahui bahwa kinerja museum dalam penyajian informasi secara berurutan terjadi kesenjangan dalam ragam, misteri, dan keterkaitan antara informasi. Di lain pihak penyajian informasi dengan indikator desain dan tafsiran menunjukkan kesenjangan yang lebih rendah. 


\section{KESIMPULAN}

Berdasarkan uraian pada bab-bab di atas, dapat disimpulkan beberapa hal terkait dengan pengelolaan informasi dalam pameran di Museum Sonobudoyo untuk mengetahui tingkat persepsi pengunjung museum melalui kajian persepsi model Kaplan.

a) Museum merupakan tempat yang sangat bernilai dalam perjalanan hidup suatu bangsa dan menyimpan berbagai karya luhur nenek moyang yang mencerminkan kekayaan dan keanekaragaman budaya yang penting artinya bagi pembelajaran. Karena itu, museum sebagai lembaga yang bertugas menyelenggarakan pameran untuk menyajikan hasil pencapaian kebudayaan dan peradaban harus dapat mengemas informasinya untuk kepentingan pendidikan, penelitian, dan hiburan atau enjoyment.

b) Kemasan-kemasan informasi dalam presentasi melalui pameran koleksi museum didasarkan pada penentuan isi dan pesan. Isi dan pesan disusun melalui proses encoding (pengalihan pikiran ke dalam bentuk lambang) dan selanjutnya disajikan dalam media primer (objek/koleksi) dan media sekunder (label, fotografi, gambar, peta, dan multi media). Sajian pesan ini akhirnya dicoba dipahami melalui proses decoding oleh pengunjung. Untuk mencapai tingkat akurasi persepsi yang tinggi antara komunikator dengan komunikan, sebagai inti dari komunikasi, maka pameran sebaiknya berpedoman pada persepsi model Kaplan yaitu informasi yang disajikan harus koheren, mudah difahami, kompleks, dan mengandung misteri.

c) Keempat variabel persepsi model Kaplan digunakan untuk mengetahui sejauhmana tingkat akurasi persepsi antara komunikator (pengelola museum) dengan komunikan (pengunjung museum) di Museum Sonobudoyo, melalui penyebaran kuesioner kepada 65 responden. Hasilnya menunjukkan masih terjadi kesenjangan antara kinerja museum dengan akurasi persepsi pengunjung terhadap kemasan informasi yang tersedia.

- Kesenjangan tertinggi terjadi pada penyajian kemasan tulis berupa brosur, leaflet, dan buku panduan.

- Kesenjangan kedua yang lebih rendah adalah pada tampilan, tingkat pemahaman, dan kompleksitas informasi kemasan tulisan visual

- Kesenjangan ketiga terjadi pada ragam, misteri, keterkaitan antara informasi, dan desain.

Diharapkan hasil penelitian ini dapat digunakan untuk meningkatkan kualitas pameran di Museum Sonobudoyo, sehingga pesan-pesan yang hendak disampaikan dapat secara lebih tepat dipahami oleh pengunjung. 


\section{KEPUSTAKAAN}

Anonim, 2001. Welcome to Sonobudoyo Museum Yogyakarta. Yogyakarta: Museum Negeri Propinsi Daerah Istimewa Yogyakarta Sonobudoyo

Azwar, Saifuddin. 1998. Metode Penelitian. Yogyakarta: Pustaka Pelajar.

Effendi, Onong Uchjana. 2003. IImu, Teori, dan Filsafat Komunikasi. (cetakan III). Bandung: Penerbit PT Citra Aditya Bakti.

Hooper-Greenhill, Eilean, 1999. "Communication in Theory and Practice". In Eilean Hooper-Greenhill (ed) Educational Role of the Museum. Pp. 28-52. London: Routledge

Howard, Peter. 2003. Heritage, Management, Interpretation, Identity. London: Continuum

Mulyana, Deddy, 2007. IImu Komunikasi Suatu Pengantar. (cetakan XI). Bandung: Penerbit PT Remaja Rosdakarya.

Poespowadojo, Soerjanto. 1993/1994. "Arkeologi dan Jatidiri Bangsa". Dalam Proceedings Pertemuan IImiah Arkeologi VI. Jakarta: Pusat Penelitian Arkeologi Nasional. HIm. 15-21.

Prasodjo, Tjahyono, 2004. Arkeologi Publik. Makalah dalam Pelatihan Pengelolaan Sumberdaya Arkeologi Tingkat Dasar di Trowulan.

Sarwono, Sarlito Wirawan, 1992. Psikologi Linkungan. Jakarta: Grasindo

Sedyawati, Edi, "Kajian Kuantitatif atas Masalah Local Genius", Pertemuan IImiah Arkeologi IV, Jakarta: Puslitarkenas, 1986, hlm. 33-49.

Setyanto, Stef Daniar Wikan, 2009. Psikologi Persepsi dan Desain Komunikasi Visual.

Subarnas, Bambang 2005. "Pengelolaan Pameran di Museum: Upaya Membangun Kepentingan Publik". Makalah diskusi di Museum Sri Baduga, Bandung tgl. 3-4 Oktober

Tanudirjo, Daud Aris, 2007. "Museum sebagai Mitra Pendidik" Museografia, Majalah IImu Permuseuman Vol.1, No. 1 - September. Jakarta: Departemen Kebudayaan dan Pariwisata, Direktorat Museum. HIm. $15-32$. 